Neth. J. Pl. Path. 96 (1990) 3-15

\title{
Genetic variation in partial resistance to leaf rust in winter wheat: disease progress, foliage senescence and yield reduction
}

\author{
C.J.T. SPITTERS ${ }^{1,3}$, H.J.W. VAN ROERMUND'2, H.G.M.G. VAN NASSAU', J. SCHEPERS ${ }^{\prime}$ \\ and J. MESDAG' \\ 1 Foundation for Agricultural Plant Breeding (SVP), P.O. Box 117, 6700 AC Wageningen, the \\ Netherlands \\ ${ }^{2}$ Department of Theoretical Production Ecology, Wageningen Agricultural University, P.O. \\ Box 430, 6700 AK Wageningen, the Netherlands \\ 3 Present address: Centre for Agrobiological Research (CABO), P.O. Box 14, 6700 AA Wagen- \\ ingen, the Netherlands
}

Accepted 20 September 1989

\begin{abstract}
Relations between leaf rust progress, foliage senescence and yield reduction were studied for seven winter wheat genotypes, differing in their partial resistance to leaf rust. Leaf rust accelerated leaf and ear senescence. Photosynthesis measurements showed, however, that the photosynthetic capacity of the remaining green surface was not affected. Differences between genotypes in yield reduction were largely explained by differences in leaf senescence and, therefore, in cumulative light interception $(r=0.83)$ and crop photosynthesis. Reduction in cumulative light interception was closely related to the arca under the discase-progress-curve $(r=0.85)$, which was also closely associated with yield reduction $(r=0.88)$. However, the time taken to reach a $50 \%$ reduction of green leaf area and the pustule density on 1 July (i.e. halfway through the epidemic) were just as good predictors of yield reduction as cumulative light interception and area under diseaseprogress-curve, suggesting that the former are useful criteria in the selection for partial resistance to leaf rust.
\end{abstract}

Additional keywords: Puccinia recondita, Triticum aestivum, Photosynthesis.

\section{Introduction}

Leaf rust infection (Puccinia recondita Rob. ex. Desm. f.sp. tritici) causes yield reduction in winter wheat (Triticum aestivum L.) which was reviewed as early as 1946 by Chester. Variation in yield reduction depends on a combination of resistance and tolerance of the crop and virulence of the rust race. Crop resistance is defined as the ability of the host to hinder the infection and/or growth of the pathogen. Partial resistance is a form of incomplete resistance in which spore production is reduced even though the host plants are susceptible to infection (susceptible infection type) (Parlevliet, 1979). Partial resistance can be assessed by measuring the amount of disease and by screening the infection type. Partial resistance of winter wheat to leaf rust has been reported by Ohm and Shaner (1976), Kuhn et al. (1978) and Rees et al. (1979).

Leaf rust causes pustules on the leaves and accelerated foliage senescence, the latter reducing final yield. The aim of this study is to express genetic variation in yield reduc- 
tion in components of rust epidemiology and crop physiology. Relations between disease progress, foliage senescence and yield reduction were studied for seven winter wheat genotypes differing in their partial resistance to leaf rust. Questions raised are to what extent genetic variation in yield reduction can be explained by a difference in acceleration of foliage senescence and whether senescence is a useful criterion in selection for partial resistance and tolerance to leaf rust.

\section{Materials and methods}

Experimental design. A field experiment was carried out in 1985/1986 at Lelystad (East Flevopolder, the Netherlands). Seven winter wheat genotypes were studied in two treatments (control, inoculated), with each combination in three replicates. The seven winter wheat genotypes were 'Cappelle Desprez', 'Okapi', 'Heine's Il', 'Halle stamm

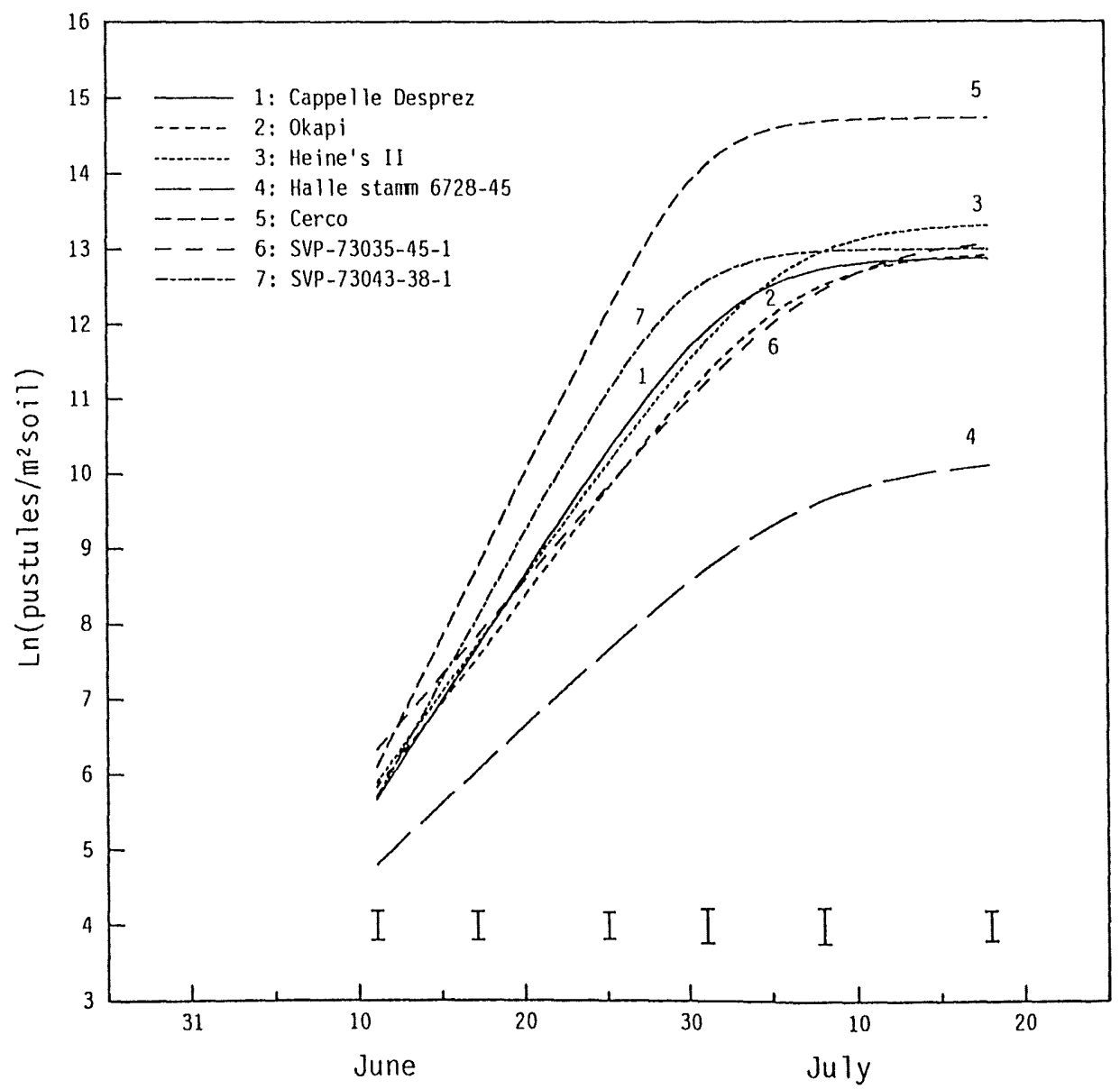

Fig. 1. Seasonal courses of pustule density (Ln-scale) fitted for each winter wheat genotype by a logistic function. Time is given in days. Bars represent standard errors (SE) of the (nonreproduced) data points. 
6728-45', 'Cerco', 'SVP-73035-45-1' and 'SVP-73043-38-1'. Plot size was $3 \mathrm{~m} \times 4 \mathrm{~m}$, the central $3 \mathrm{~m} \times 3 \mathrm{~m}$ of which were harvested for yield determination. To minimize interplot interference, the inoculated plots were separated from each other by $21 \mathrm{~m}$ wide borders of (nonhost) winter barley and the control plots were situated $50 \mathrm{~m}$ west of the inoculated plots (upwind in the prevailing wind direction). The genotypes were sown on 22 October 1985. In spring 1986, a nitrogen dressing of $60 \mathrm{~kg} \mathrm{ha}^{-1}$ was applied. During the growing season, Milgo E was applied to control mildew, and on 15 May $1986 \mathrm{CCC}\left(1.5 \mathrm{I} \mathrm{ha}^{-1}\right)$ was applied to prevent lodging. Leaf rust ('Limburg' isolate with intermediate virulence) was inoculated by placing four, heavily artificially infected, winter wheat plants into each plot from 21 May to 31 May (genotype 'Scalavatis 56'; development stage DC 32-33, Zadoks et al., 1974). On 31 May, the first pustules were visible. Each week from 11 June (DC 40) until 12 August (DC 92), 20 randomly chosen culms per replicate were selected for records on:

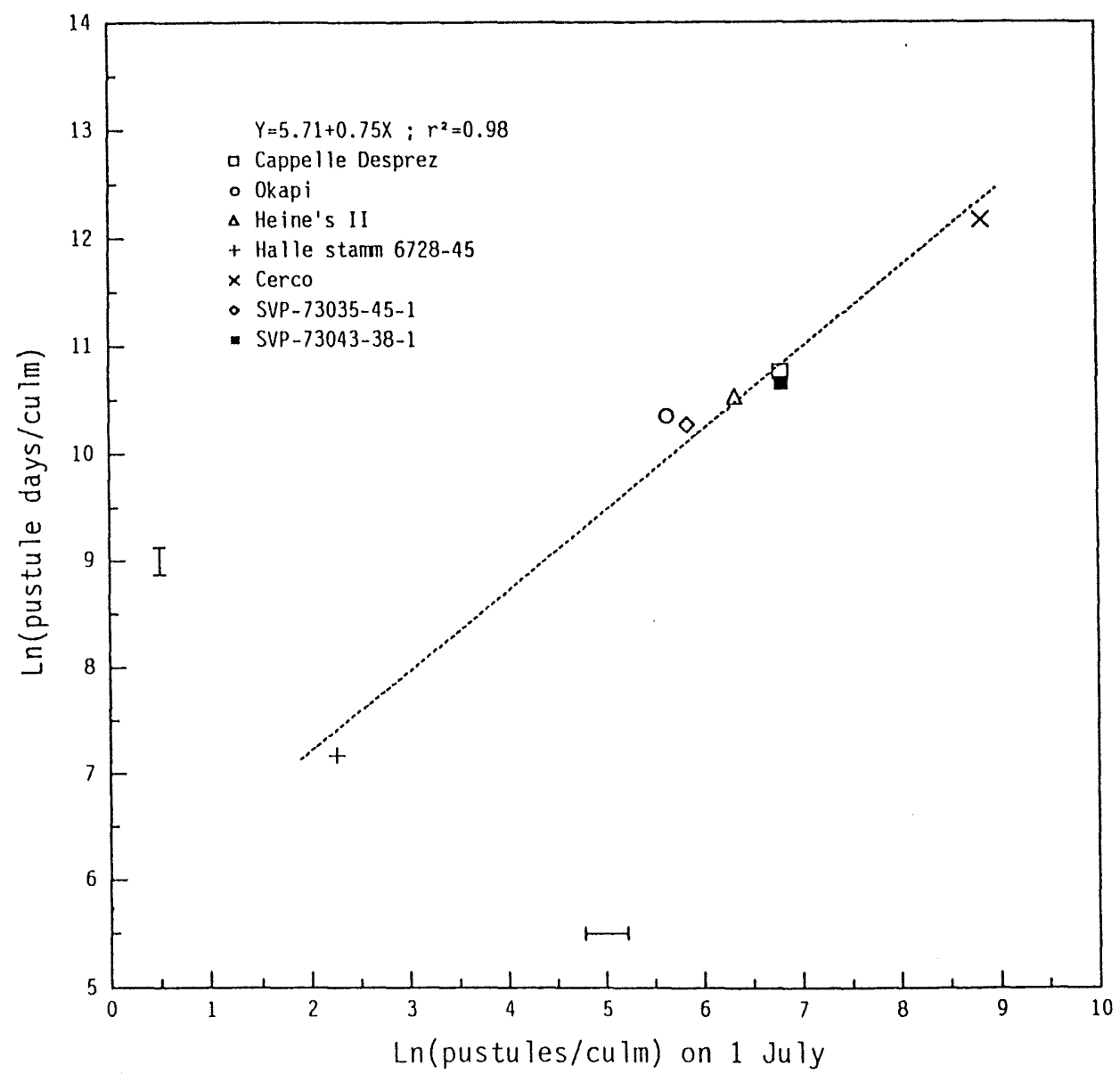

Fig. 2.Relationship between pustule density on $1 \mathrm{July}$ and cumulative disease intensity (in pustule days per culm) as measured by the area under disease-progress-curve. Bars represent standard errors (SE).

Neth. J. Pl. Path. 96 (1990) 
a Table 1. Parameters of logistic growth $\left(N_{0}=10 \mathrm{~m}^{-2}\right.$ ground), area under disease-progress-curve in pustule days, infection type, leaf area per culm ( 3 upper leaves) and ear size (measured one-sided) of control plants just prior to anthesis, cumulative light (PAR) absorption from 20 June onwards (start of anthesis of 'Cerco'), time between start of anthesis and reduction of LAI to half the maximum value $\left(t_{\mathrm{L} 50}\right)$, culm density, and reduction in kernel weight. The variation within and among genotypes is characterized by the environmental coefficient of variation $\left(C V_{\mathrm{e}}=\right.$ standard error/overall mean) and by the genetic coefficient of variation $\left(C V_{\mathrm{g}}=\right.$ genetic standard deviation/overall mean), respectively.

\begin{tabular}{|c|c|c|c|c|c|c|c|c|c|c|c|c|c|}
\hline \multirow[t]{4}{*}{ Wheat genotype } & \multirow{2}{*}{\multicolumn{2}{|c|}{$\begin{array}{l}\text { Logistic growth } \\
\text { curve } \\
\end{array}$}} & \multirow{3}{*}{$\begin{array}{l}\text { Pustule } \\
\text { days } 11\end{array}$} & \multirow{3}{*}{$\begin{array}{l}\text { Infec- } \\
\text { tion } \\
\text { type }\end{array}$} & \multicolumn{2}{|c|}{ Area per culm } & \multirow{2}{*}{\multicolumn{2}{|c|}{$\begin{array}{l}\text { Cum. absorbed } \\
\text { light }\end{array}$}} & \multicolumn{2}{|l|}{$\left.t_{\mathrm{L} 50^{2}}\right)^{2}$} & \multicolumn{2}{|c|}{ Culm density } & \multirow{3}{*}{$\begin{array}{l}\% \text { Reduc- } \\
\text { tion in } \\
1000- \\
\text { kernel } \\
\text { weight }\end{array}$} \\
\hline & & & & & \multirow{2}{*}{ leaf } & \multirow[t]{2}{*}{ ear } & & & \multirow{2}{*}{ control } & \multirow{2}{*}{$\begin{array}{l}\text { inocu- } \\
\text { lated }\end{array}$} & \multirow[t]{2}{*}{ control } & \multirow{2}{*}{$\begin{array}{l}\text { inocu- } \\
\text { lated }\end{array}$} & \\
\hline & $r$ & $N_{\mathrm{m}}$ & & & & & control & $\begin{array}{l}\text { inocu- } \\
\text { lated }\end{array}$ & & & & & \\
\hline & $d^{-1}$ & $\begin{array}{l}\mathrm{N} \mathrm{m}^{-2} \\
\text { ground } \\
\left(\times 10^{4}\right)\end{array}$ & $\begin{array}{l}\mathrm{N} \\
\text { culm }^{-1} \mathrm{~d} \\
\left(\times 10^{4}\right)\end{array}$ & - & \multicolumn{2}{|c|}{$\mathrm{cm}^{2}$} & \multicolumn{2}{|c|}{$\mathrm{MJ} \mathrm{m}^{-2}$ ground } & \multicolumn{2}{|c|}{ d } & \multicolumn{2}{|c|}{ culms $\mathrm{m}^{-2}$} & \\
\hline 'Cappelle Desprez' & 0.32 & 40.4 & 4.67 & 9 & 79.4 & 11.2 & 252 & 140 & 34.2 & 18.4 & 321 & 219 & 18.7 \\
\hline ‘Okapi’ & 0.30 & 38.1 & 3.14 & 9 & 63.5 & 10.4 & 240 & 156 & 34.2 & 21.1 & 363 & 290 & 10.0 \\
\hline 'Heine's II' & 0.32 & 58.3 & 3.74 & 8 & 70.9 & 9.9 & 237 & 148 & 27.7 & 17.0 & 414 & 302 & 16.7 \\
\hline 'Halle stamm $6728-45$ ' & 0.22 & 25.1 & 0.13 & 9 & 65.2 & 9.8 & 224 & 207 & 30.8 & 25.9 & 357 & 397 & 3.2 \\
\hline 'Cerco' & 0.39 & 260.3 & 19.16 & 9 & 57.5 & 16.8 & 172 & 104 & 29.7 & 12.9 & 299 & 322 & 18.8 \\
\hline 'SVP-73035-45-1' & 0.31 & 35.9 & 2.88 & 9 & 74.7 & 12.1 & 180 & 162 & 24.8 & 19.3 & 250 & 288 & 10.7 \\
\hline 'SVP-73043-38-1' & 0.35 & 47.7 & 4.21 & 9 & 72.0 & 9.8 & 237 & 139 & 32.2 & 15.3 & 322 & 295 & 14.2 \\
\hline mean & 0.31 & 72.3 & 5.42 & - & 69.0 & 11.4 & 220 & 151 & 30.7 & 18.6 & 332 & 302 & 13.1 \\
\hline $\mathrm{SE}$ & 0.006 & - & - & - & $0.8^{+1}$ & 0.13 & 10.9 & 7.2 & 0.63 & 0.86 & 28 & 24 & 2.3 \\
\hline$C V_{0}$ & 0.018 & $0.324^{3)}$ & $0.255^{31}$ & - & $0.011^{4)}$ & 0.011 & 0.049 & 0.048 & 0.021 & 0.046 & 0.083 & 0.079 & 0.175 \\
\hline$C V_{g}$ & 0.16 & $1.34^{3\}}$ & $1.37^{3)}$ & - & 0.11 & 0.22 & 0.13 & 0.20 & 0.12 & 0.18 & 0.13 & 0.16 & 0.39 \\
\hline
\end{tabular}


- Leaf rust progress. Number of pustules were scored on the three upper leaves according to a logarithmic scale (modified after Parlevliet and van Ommeren, 1975).

- Foliage senescence. The green percentages of leaf area and ear area were estimated visually, and total leaf and ear size were measured (one-sided) by an electronic planimeter. Leaf area index (LAI) and ear area index (EAI) were calculated by multiplying culm density, maximum leaf or ear area per culm, and the visually estimated green percentages of leaves and ears.

- Leaf photosynthesis. Flag leaf photosynthesis of the genotypes 'Cappelle Desprez', 'Okapi' and 'SV P-73043-38-1' was measured in the field using an ADC portable leaf chamber gas analyser. All measurements were made at light saturation ( $1700 \mu$ mol quanta $\mathrm{m}^{2} \mathrm{~s}^{1}$ ) provided by an incandescent lamp cooled by a fan.

- Development stage of the crop, according to Zadoks et al. (1974).

On 18 August, 200 culms were taken randomly from each plot and the rest was harvested using a precision combine harvester. Total grain weight, 1000-kernel weight and culm density were measured per plot.

Statistical analyses. The collected data were subjected to an analysis of variance to estimate standard error of the means (SE), environmental coefficient of variation, i.e. the standard error divided by the overall mean $\left(\mathrm{CV}_{\mathrm{c}}\right)$, and the genetic coefficient of variation, i.e. the genetic standard deviation divided by the overall mean $\left(C V_{\mathrm{g}}\right)$.

The leaf rust progress was fitted by a logistic function of time:

$$
N_{\mathrm{t}}=N_{\mathrm{m}} /\left(1+\left(\left(N_{\mathrm{m}}-N_{0}\right) / N_{0}\right) \cdot \mathrm{e}^{r \prime}\right)
$$

where $N$ is the pustule density, with subscripts $t$ and 0 referring to times $t$ and 0 and $\mathrm{m}$ to the maximum density; $r$ is the apparent infection rate (VanderPlank, 1963) and approximates the relative growth rate at time 0 . Time of start of the epidemic $\left(t_{0}\right)$ was assumed to be 31 may (day 151), being the day when the first pustules were observed in the field. This was 10 days or 125 degree days $\left({ }^{\circ} \mathrm{C}\right.$ d, daily average temperatures were accumulated above a base of $0{ }^{\circ} \mathrm{C}$ ) after inoculation. The parameters $N_{0}, N_{\mathrm{m}}$ and $r$ were estimated by a least squares procedure using data of $\ln \left(N_{1}\right)$ per plot as input. The logarithmic values were taken to ensure homogeneity of variances. The average growth curve per genotype was fitted by a joint regression over the three replicates of the genotype. To estimate SE, $C V_{\mathrm{c}}$ and $C V_{\mathrm{p}}$ of the parameters, however, the logistic function was fitted per plot, whereafter the parameter estimates were subjected to an analysis of variance.

\section{Results}

Disease progress. The disease progress in the field was described well by a logistic function and Fig. 1 shows the fitted functions of pustule density for the seven winter wheat genotypes. Pustule density is expressed per unit ground area because of the equal inoculum densities per plot on inoculation (21 May); densities can be transformed into pustules culm ' using the culm density. Pustule density decreased after 18 July, due to advanced foliage senescence.

The disease progress can be characterized by the three parameters defining the logistic growth curve: $N_{0}, r$ and $N_{\mathrm{m}}$. Estimates of $N_{0}$ and $r$ showed a very high error correla- 


\section{CONTROL}

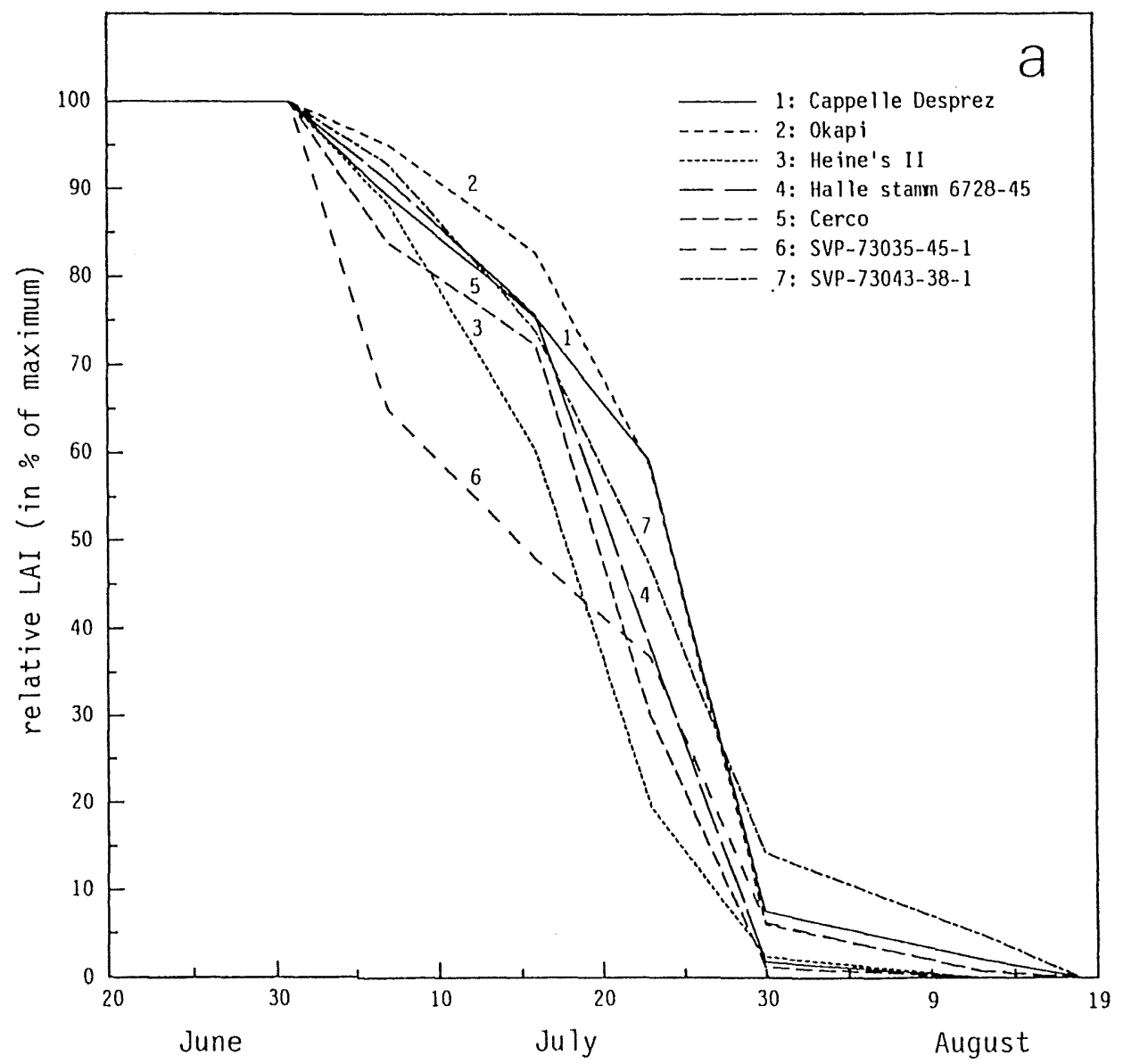

Fig. 3. Time course of relative leaf area index (a) in the absence and (b) in the presence of leaf rust.

tion, which biases the comparison of the genotypes for $r$. The genotypes did not differ significantly for $N_{0}(\mathrm{P}>0.05)$, so the logistic function was fitted again using the overall geometric mean of 10 pustules $\mathrm{m}^{-2}$ ground as a fixed value for $N_{0}$ (Table 1). The 3-parameter model gives a more precise description of the time course and was therefore used in Fig. 1, while the 2-parameter model gives a better estimate of the initial apparent infection rate.

The integrated disease intensity is characterized by the area under disease-progresscurve (in pustule days, Table 1). From the six weekly observation dates, the pustule density on 1 July showed the highest correlation with the integrated disease intensity $\left(r^{2}=\right.$ 0.976 , Fig. 2), and demonstrated also the highest genotypic variation $\left(\sigma_{g}=2.05\right.$ for $\mathrm{Ln}(\mathrm{N})$ ). Thus, pustule density on $1 \mathrm{July}$ was the best single predictor of total disease intensity and also enabled optimal discrimination between genotypes (see also Fig. 1). 


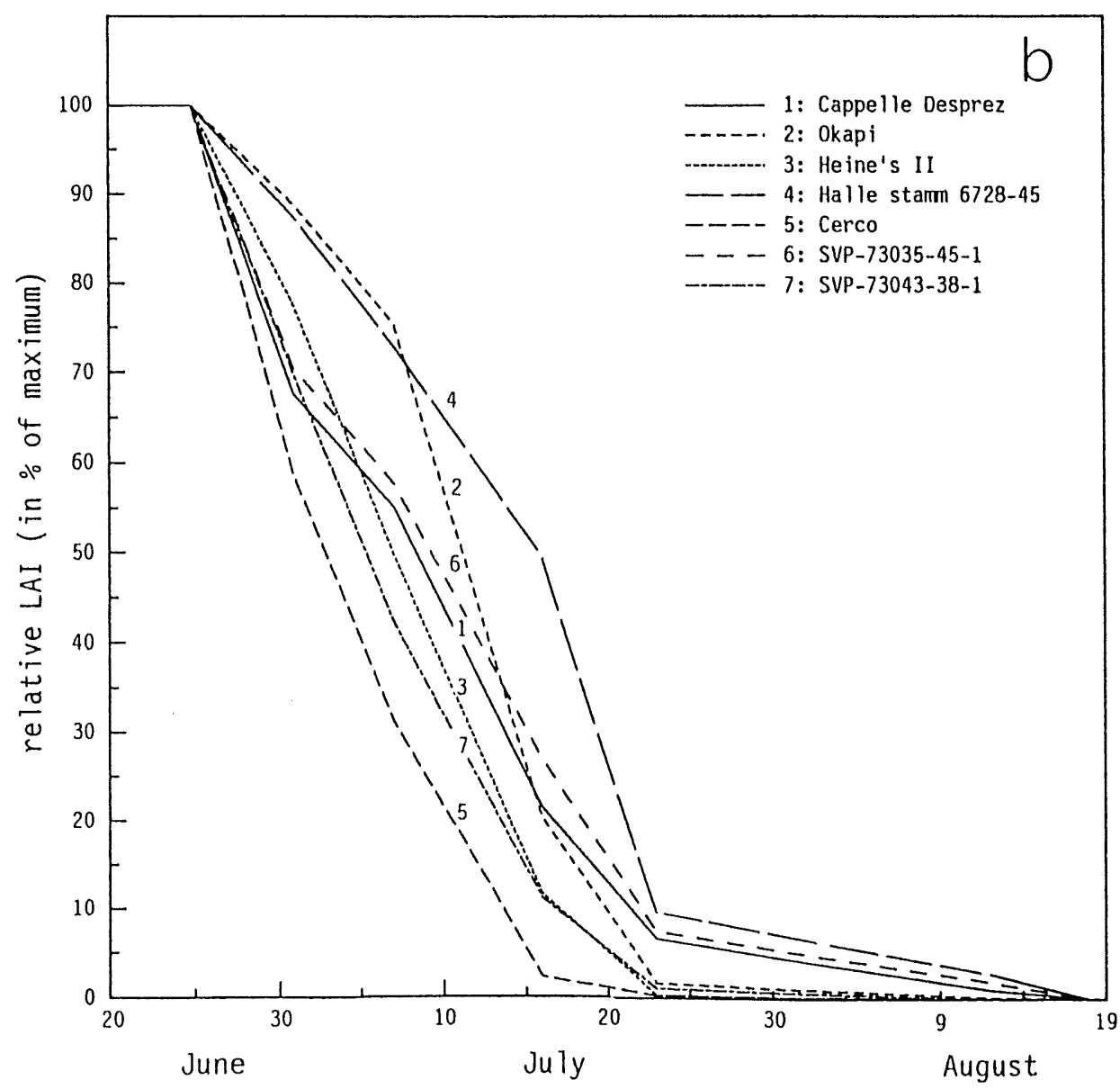

The wheat genotypes used in the experiment can be distinguished into three different groups when disease resistance is concerned (Figs. 1 and 2, Table 1): relatively resistant ('Halle stamm 6728-45'), moderately resistant ('Cappelle Desprez', 'Okapi', 'Heine's II', 'SVP-73035-45-1', 'SVP-73043-38-1') and relatively sensitive ('Cerco'). The infection type (McNeal et al., 1971) of leaf rust symptoms in the field hardly differed between the genotypes (Table 1).

Correlations between disease intensity and apparent infection rate, maximum pustule density, latent period, infection frequency and pustule size are given in Table 2 . The latent period, as defined by Parlevliet (1975), is the time between inoculation and 50\% of maximum sporulating pustule density, which was measured in an additional greenhouse experiment in 1986. Infection frequency, defined here as the maximum sporulating pustule density, and pustule size were derived from the same greenhouse experiment. 
Table 2. Phenotypic correlations between genotype means for the logarithm of area under diseaseprogress-curve and pustule density on $1 \mathrm{July}$ on the one hand and the apparent infection rate $(r)$, maximum pustule density $\left(N_{\mathrm{m}}\right)$, latent period, infection frequency and pustule size on the other.

\begin{tabular}{|c|c|c|c|c|c|}
\hline & $r$ & $N_{\mathrm{m}}$ & $\begin{array}{l}\text { Latent } \\
\text { period }\end{array}$ & $\begin{array}{l}\text { Infection } \\
\text { frequencey }\end{array}$ & $\begin{array}{l}\text { Pustule } \\
\text { size }\end{array}$ \\
\hline Ln(pustule days) & 0.969 & 0.989 & $-0.41^{*}$ & 0.68 & $0.41^{*}$ \\
\hline Ln(N) on 1 July & 0.986 & 0.980 & $-0.36^{*}$ & 0.60 & $0.22 *$ \\
\hline
\end{tabular}

* 'Halle stamm 6728-45' not included because no pustules developed on this genotype in the glasshouse.

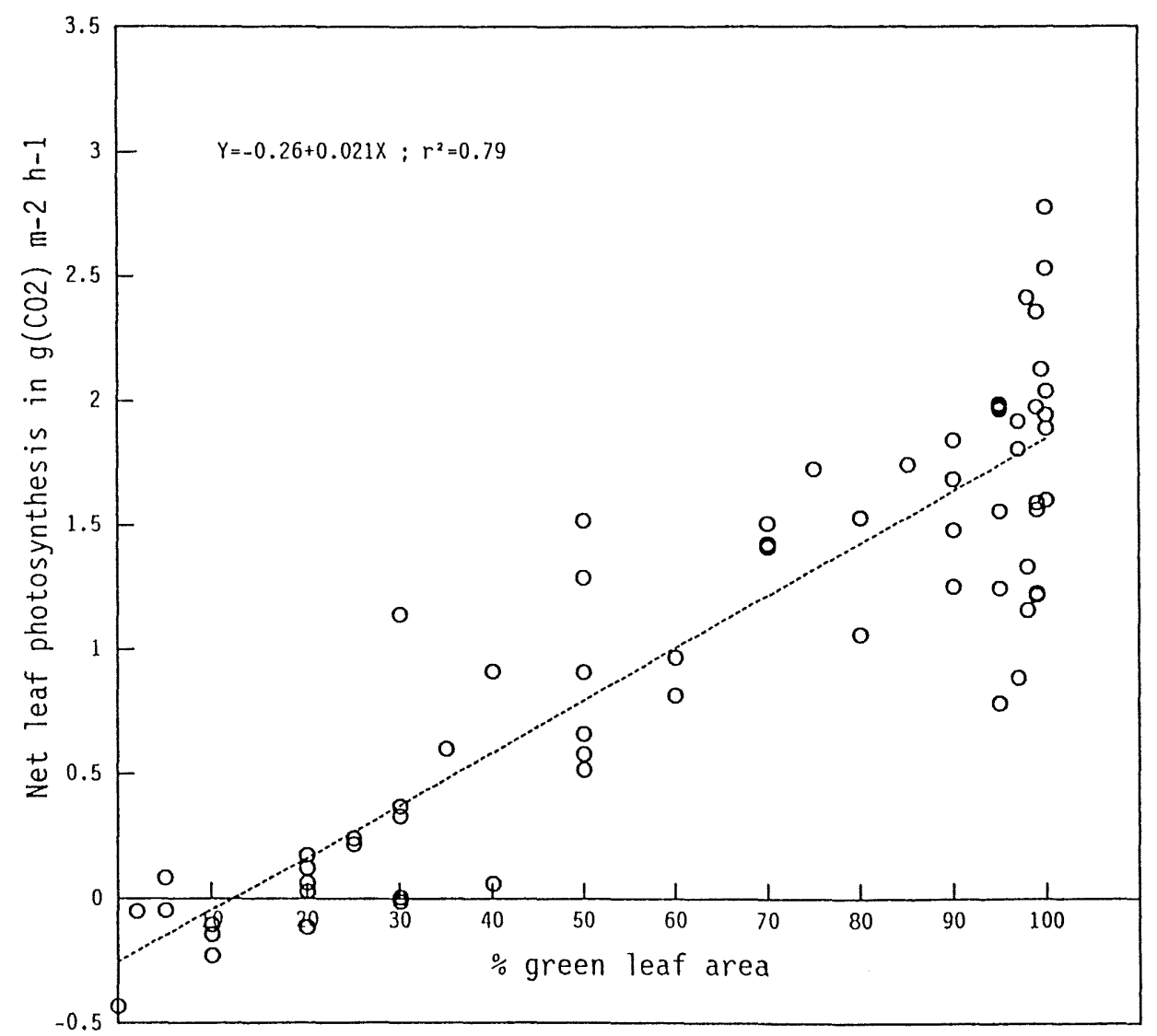

Fig. 4. Net photosynthesis at light saturation as a function of the percentage green of single, infected leaves of 'Cappelle Desprez' in the field. 
Foliage senescence. Foliage senescence started earlier and proceeded at a faster rate in the presence than in the absence of leaf rust (Fig. 3). Wheat genotypes may differ in their reaction, as illustrated by the difference in early leaf senescence in 'Cappelle Desprez' and 'SVP-73043-38-1' (Fig. 3b) in spite of a similar leaf rust development (Fig. 1). Leaf rust will reduce cumulative crop photosynthesis due to reduced light interception resulting from accelerated foliage senescence. The photosynthetic capacity of the leaves (measured by their rate of photosynthesis at light saturation) was related linearly to the green percentage of single leaves over the whole senescence range, as measured for 'Cappelle Desprez' (Fig. 4), 'Okapi' and 'SVP-73043-38-1'. Hence the photsynthetic capacity per unit of green leaf area was not affected by the rust, suggesting that visual estimation of green leaf area is a useful measure of reduction in photosynthesis due to leaf rust.

The rate of crop grwoth is usually linearly related to the light interception by the foliage (e.g. Gosse et al., 1986). Cumulative light absorption after anthesis was therefore calculated as a measure of total crop photosynthesis during the grain filling stage (Table 1). The cumulative absorbed photosynthetically active radiation (PAR, 400-700 nm) by green area was calculated from measured incoming radiation using a light extinction coefficient of 0.7 for leaves and 0.3 for the above-positioned ear layer (Groot, 1987; ear area measured one-sided).

Due to the roughly linear decrease in green leaf area after anthesis, the time after anthesis at which the $\mathrm{LAI}$ is reduced to $50 \%$ of its maximum $\left(t_{\mathrm{L} 50}\right)$ was closely related to the cumulative light absorption $(r=0.99$, Table 3$)$ and can thus be used as a single predictor of cumulative light absorption and photosynthesis during the grain filling stage. Even more practical will be the use of a visual estimate of the ground coverage by green foliage around this time as a selection criterion. The genotypic differences in $t_{1.50}$ were greater in the presence than in the absence of leaf rust (Table 1; $C V_{\mathrm{g}}=$ 0.18 versus 0.12 ).

Pustule coverage itself has a neglible effect on the reduction in light interception (Van Roermund and Spitters, 1990).

Yield reduction. Yield reduction due to leaf rust infection was estimated by the observed reduction of 1000-kernel weight between control and inoculation treatments rather than by the observed reduction in total grain yield. This was done because heterogeneity in the seedbed caused a variable stand density, generating yield differences not associated

Table 3. Phenotypic correlations among genotype means for reduction in kernel weight, cumulative light absorption after anthesis and time between anthesis and reduction of LAI to half the maximum value, logarithm of area under disease-progress-curve and pustule density on 1 July.

1

2

3

4

1. $\%$ Reduction in kernel weight

2. $\%$ Reduction in cumulative light absorption $\quad 0.83$

3. $\%$ Reduction in $t_{1.50}$

4. Ln(pustule days per culm) 0.88

5. $\mathrm{Ln}(\mathrm{N}$ per culm) on $1 \mathrm{July} \quad 0.91$

0.99

0.85

0.87

0.99

Neth. J. Pl. Path. 96 (1990) 


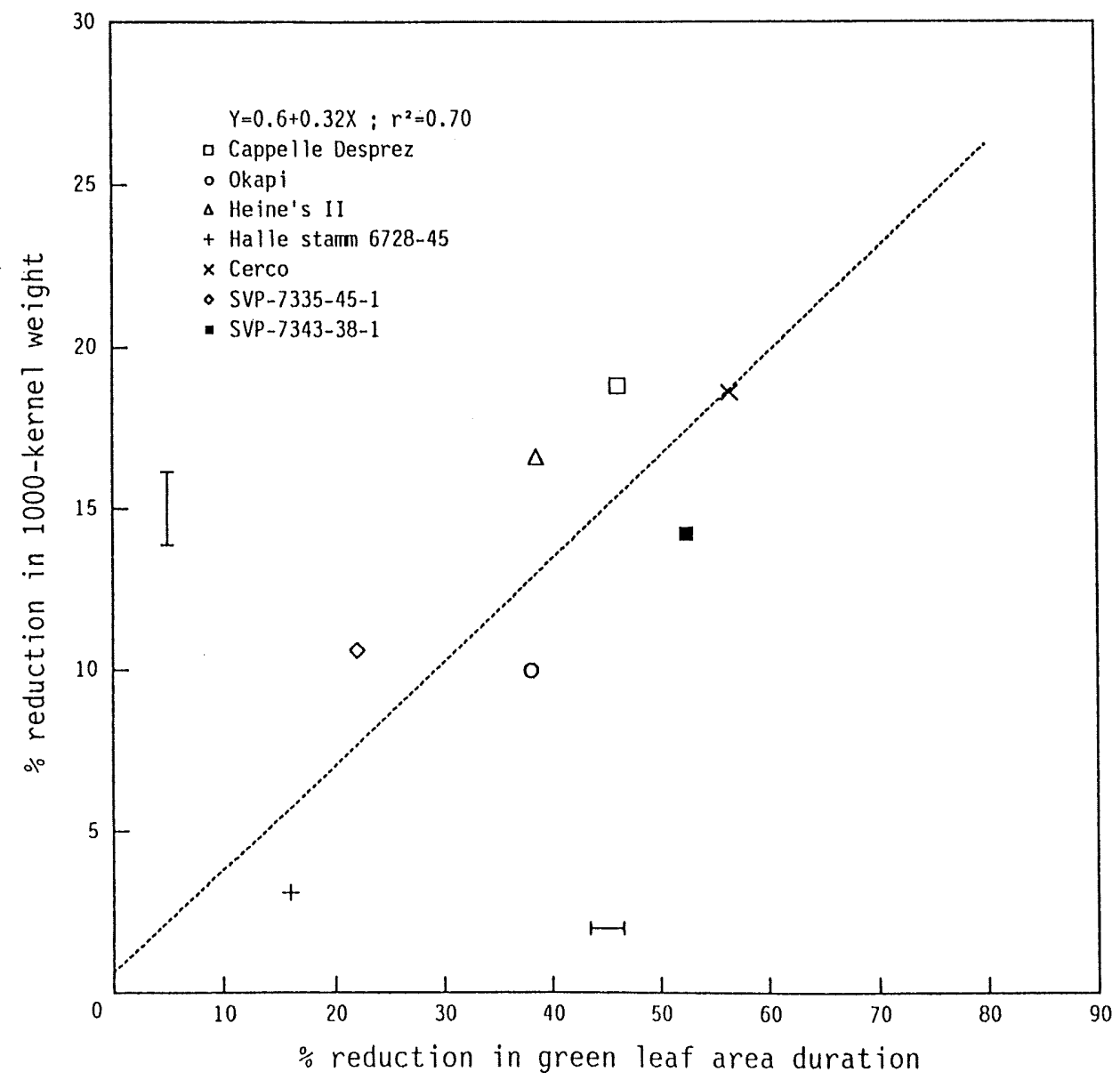

Fig. 5. Relationship between $\%$ reduction in 1000-kernel weight and $\%$ reduction in time after anthesis (of 'Cerco') at which the LAI is reduced to $50 \%$ of its maximum $\left(t_{1.50}\right)$. Bars represent standard errors (SE).

with disease incidence, but with variation in culm density (Van Roermund and Spitters, 1990). The 1000-kernel weight would have been less affected by the heterogeneity in stand density. Moreover, the epidemic began just before anthesis and would have affected mainly 1000-kernel weight with little influence on culm density and kernel per culm.

Leaf rust caused a high yield reduction in 'Cerco' and 'Cappelle Desprez' and a low reduction in 'Halle stamm 6728-45' (Table 1). These differences were associated with the variation among the genotypes in disease progress and foliage senescence (Table 3). Time taken to reach $50 \%$ reduction of the leaf area index and pustule density on 1 July were just as good predictors of yield reduction as cumulative light absorption and area under disease-progress-curve (Table 3, Figs. 5 and 6). 


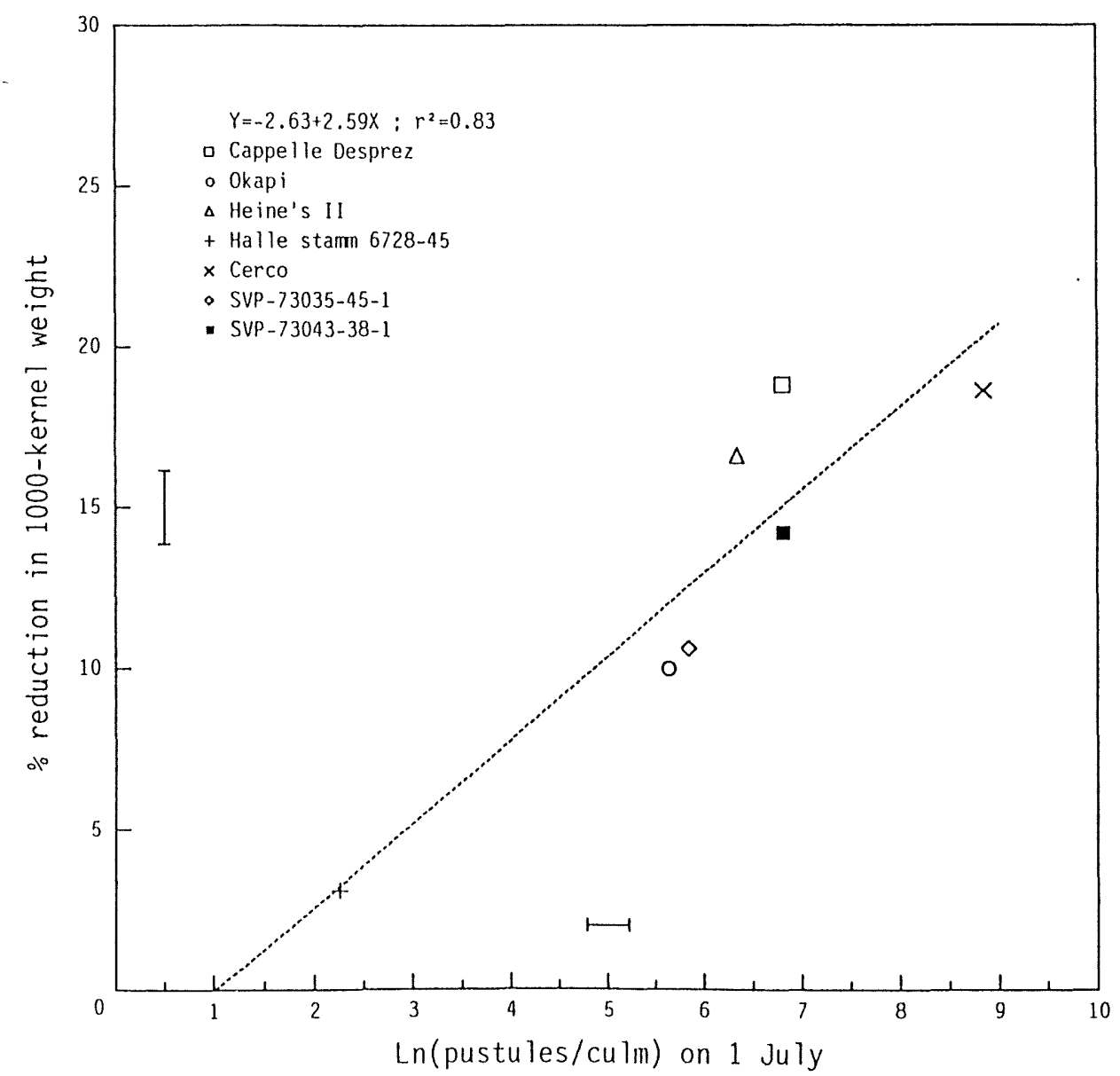

Fig. 6. Relationship between $\%$ reduction in 1000-kernel weight and pustule density on $1 \mathrm{July}$. Bars represent standard errors (SE).

\section{Discussion}

Differences in yield reduction of winter wheat genotypes due to leaf rust were largely explained by differences in the reduction of cumulative light interception. The rust accelerated foliage senescence, reducing the cumulative light interception of the crop and so its total dry matter production, which was proportional to the light interception. The applicability of such a crop physiological analysis to disease or pest-induced yield losses was also demonstrated by, among others, Rossing et al. (1989), Waggoner and Berger (1987), Johnson (1987), Van Roermund et al. (1986), Rabbinge et al. (1985).

The results of photosynthesis measurements in the field support the hypothesis that leaf rust in winter wheat reduces crop photosynthesis by reducing the green, photosynthesizing area without affecting the photosynthetic rate per unit of remaining green surface. Visual scores of the greenness of leaves and ears provided, therefore, a simple 
estimate of the reduction in photosynthetic capacity of the foliage. The situation may be different for other diseases, as suggested, for instance, by the results of Rabbinge et al. (1985) who found that a $4 \%$ coverage of powdery mildew in wheat reduced leaf photosynthesis by $50 \%$.

The acceleration of foliage senescence was closely related to pustule density, which may have been promoted by the similarity of the infection types. It will, therefore, be interesting to study the relationship between disease progress and leaf senescence in wheat genotypes differing in infection types.

In selection for partial resistance and tolerance, it is not feasible to use the causal criteria of cumulative light interception and area under disease-progress-curve. It was shown, however, that $t_{1.50}$ (and also the green percentage of leaf area at this time) and $\operatorname{Ln}(\mathrm{N})$ on 1 July (i.e. the amount of disease half way through the epidemic) were equally good predictors of yield reduction.

\section{Acknowledgements}

We are grateful to K. van Spanje for technical assistance cluring the experiments.

\section{Samenvatting}

Genetische variatie in partiële resistentie tegen bruine roest in wintertarwe: epidemiologie, bladveroudering en opbrengstreductie

De relatie stussen de epidemiologie van bruine roest, bladveroudering en opbrengstderving werden bestudeerd bij zeven wintertarwegenotypen die verschilden in partiële resistentie tegen bruine roest. Bruine roest versnelde de veroudering van blad en aar. Fotosynthesemetingen wezen echter uit dat de fotosynthesecapaciteit van het resterende groene oppervlak niet werd beïnvloed. Verschillen tussen de genotypen in opbrengstderving werden voornamelijk veroorzaakt door verschillen in bladveroudering en daarmee in cumulatieve lichtinterceptie $(r=0.83)$ en gewasfotosynthese. De reductie in cumulatieve lichtinterceptie was nauw gerelateerd aan de cumulatieve ziektedruk (in puistdagen) $(r=0.85)$, welke ook nauw was geassocieerd met de opbrengstderving $(r=0.88)$. De opbrengstreductie werd echter even goed voorspeld door de tijdsduur tot $50 \%$ reductie van het groene bladoppervlak en de puistdich theid halverwege de epidemie als door cumulatieve lichtinterceptie en cumulatieve ziektedruk, waardoor beide eerste criteria gebruikt kunnen worden in de selectie voor partiële resistentie tegen bruine roest.

\section{References}

Chester, K.S., 1946. The nature and the prevention of the cereal rusts as exemplified in the leaf rust of wheat. Annales Cryptogamici et Phytopathologici Vol. IV. Waltham, Mass. 269 pp.

Gosse, G., Varlet-Grancher, C., Bonhomme, R., Chartier, M., Allirand, J.M. \& Lemaire, G., 1986. Production maximale de matière sèche et rayonnement solaire intercepté par un couvert végétal. Agronomie 6: 47-56.

Groot, J.J.R., 1987. Simulation of nitrogen balance in a system of winter wheat and soil. Simulation Reports CABO-TT nr 13, Wageningen. 69 pp.

Johnson, K.B., 1987. Defoliation, disease and growth: a reply. Phytopathology 77: 1495-1497. 
Kuhn, R.C., Ohm, H.W. \& Shaner, G.E., 1978. Slow leaf-rusting resistance in wheat against twentytwo isolates of Puccinia recondita. Phytopathology 68: 651-656.

McNeal, F.H., Konzak, C.F., Smith E.P., Tate, W.S. \& Russell, T.S., 1971. A uniform system for recording and processing cereal research data. U.S. Department of Agriculture, ARS: 34-121.

Ohm, H.W. \& Shaner, G.E., 1976. Three components of slow leaf-rusting at different growth stages in wheat. Phytopathology 66: 1356-1360.

Parlevliet, J.E., 1975. Partial resistance of barley to leaf rust, Puccinia hordei. I. Ef fect of cultivar and development stage on latent period. Euphytica 24: 21-27.

Parlevliet, J.E., 1979. Components of resistance that reduce the rate of epidemic development. Annual Review of Phytopathology 17: 203-222.

Parlevliet, J.E. \& Ommeren, A. van, 1975. Partial resistance of barley to leaf rust, Puccinia hordei. II. Relationship between field trials, microplot tests and latent period. Euphytica 24: 293-303.

Rabbinge, R., Jorritsma, I.T.M. \& Schans, J., 1985. Damage components of powdery mildew in winter wheat. Netherlands Journal of Plant pathology 91: 235-247.

Rees, R.G., Thomson, J.P. \& Mayer, R.J., 1979. Slow rusting and tolerance to rusts in wheat. 1. the progress and effects of epidemics of Puccinia graminis tritici in selected wheat cultivars. Australian Journal of Agricultural Research 30: 403-419.

Roermund, H.J.W. van, Groot, J.J.R., Rossing, W.A.H. \& Rabbinge, R., 1986. Calculation of aphid damage in winter wheat, using a simulation model. Mededelingen Faculteit Landbouwwetenschappen Rijksuniversiteit Gent, 51/3a: 1125-1130.

Roermund, H.J.W. van \& Spitters, C.J.T., 1990. Simulation of yield reduction by leaf rust in winter wheat, applied to the analysis of genetic variation in partial resistance. Netherlands Journal of Plant Pathology 96: 17-28.

Rossing, W.A.H., Groot, J.J.R. \& Roermund, H.J.W. van, 1989. Simulation of aphid damage in winter wheat; a case study. In: R. Rabbinge, S.A. Ward \& H.H. van Laar (Eds), Simulation and systems management in crop protection. Simulation Monographs, Pudoc, Wageningen, $420 \mathrm{pp}$.

VanderPlank, J.E., 1963. Plant diseases: Epidemics and control. Academic Press, New York, London. 349 pp.

Waggoner, P.E. \& Berger, R.D., 1987. Defoliation, disease and growth. Phytopathology 77: 393-398.

Zadoks, J.C., Chang, T.T. \& Konzak, C.F., 1974. A decimal code for the growth stages of cereals. Eucarpia Bulletin 7. $11 \mathrm{pp}$. 